\title{
Induksi Pembungaan Jeruk Keprok Garut Melalui Pemangkasan Akar, Penyungkupan Tajuk, dan Strangulasi
}

\author{
Flowering Induction of Citrus by Root Prunning, Canopy Shading and Strangulation
}

\author{
Mohamad Akhbar Maulana, Roedhy Poerwanto*, dan Darda Efendi \\ Departemen Agronomi dan Hortikultura, Fakultas Pertanian, Institut Pertanian Bogor \\ (Bogor Agricultural University), Jl. Meranti, Kampus IPB Darmaga, Bogor 16680, Indonesia \\ Telp. \& Faks.62-251-8629353 e-mail agrohort@apps.ipb.ac.id \\ *Penulis Korespondensi : roedhy8@ yahoo.com \\ Disetujui : 30 November 2018 / Published Online 06 Mei 2019
}

\begin{abstract}
Flowering induction using excessive paclobutrazol killed the citrus plant due to the accumulation of residue in the soil. The research have been conducted to determine the effective induction technique of flowering in citrus to substituting paclobutrazol to induce flowering. The research have been conducted in Sindangbarang experimental field, Institut Pertanian Bogor in February to August 2017. The research used Randomized Complete Block Design (RCBD) with five treatments: control, strangulation, root prunning, canopy shading and paclobutrazol. Data were analyzed using analysis of varience followed further of Duncan's new multiple range test. The result showed all treatments to be affected appearance of vegetative shoots, canopy shading produced the largest number of shoots and the longest shoots length. The paclobutrazol application produced the shortest length of leaves and the narrowest width of the leaf. High rain intensity cause all physical and chemical treatments unaffect flowering initiation. Physical treatments on citrus may substituted paclobutrazol however further research have to be tested to obtain the physical treatments that can induce flowering in citrus.
\end{abstract}

Keywords: citrus, paclobutrazol, physical treatments

\section{ABSTRAK}

Induksi pembungaan menggunakan paclobutrazol secara berlebihan dapat mematikan tanaman jeruk akibat penumpukan residu dalam tanah. Penelitian ini bertujuan untuk mendapatkan teknik induksi pembungaan tanaman jeruk yang efektif dalam menggantikan paclobutrazol untuk induksi pembungaan. Penelitian dilaksanakan di kebun percobaan Institut Pertanian Bogor Sindangbarang pada bulan Februari hingga bulan Juli 2017. Percobaan menggunakan Rancangan Kelompok Lengkap Teracak (RKLT) faktor tunggal yang terdiri dari 5 perlakuan yaitu kontrol, strangulasi, pemangkasan akar, penyungkupan tajuk, dan paclobutrazol. Data dianalisis dengan analisis sidik ragam yang kemudian dilanjutkan dengan uji lanjut Duncan. Semua perlakuan termasuk kontrol mempengaruhi munculnya tunas vegetatif, perlakuan penyungkupan tajuk tanaman menghasilkan jumlah tunas paling banyak dan panjang tunas paling panjang. Aplikasi paclobutrazol menunjukkan panjang daun paling pendek dan lebar daun paling sempit. Curah hujan yang tinggi menyebabkan semua perlakuan fisik dan kimia tidak menghasilkan bunga. Perlakuan fisik pada tanaman dapat menggantikan paclobutrazol namun perlu dilakukan penelitian lebih lanjut untuk mendapatkan perlakuan fisik yang dapat menginduksi pembungaan pada tanaman jeruk.

Kata kunci: jeruk keprok, paclobutrazol, perlakuan fisik 


\section{PENDAHULUAN}

Jeruk merupakan salah satu komoditas hortikultura yang diperhitungkan pengembangannya pada periode tahun 2015-2019 karena berpotensi dalam pertumbuhan ekonomi nasional (Ditjenhort, 2014). Pertumbuhan populasi penduduk, dan gaya hidup sehat sangat berhubungan erat dengan besarnya jumlah konsumsi jeruk, terutama jeruk keprok. Peningkatan konsumsi akibat dari peningkatan jumlah konsumen tidak diiringi dengan peningkatan produksi. Produksi jeruk keprok pada tahun 2014 adalah 1785264 ton dan lebih rendah dibandingkan tahun 2010 yaitu 1937773 ton atau mengalami penurunan sebanyak $8.54 \%$ (BPS, 2015). Hal ini belum sepadan dengan volume produksi tahun 2010, sehingga memicu terjadinya peningkatan nilai impor jeruk sebesar \$ 202399 pada tahun 2014 (Respati et al., 2015). Jeruk impor yang masuk ke Indonesia berasal dari Cina dan Pakistan. Jeruk impor memiliki keunggulan seperti ukuran seragam, warna jingga cerah menarik dan permukaan kulit mulus (Nafisah et al., 2013).

Meningkatkan produksi jeruk lokal merupakan salah satu cara untuk mengurangi volume impor jeruk. Salah satu spesies tanaman jeruk yang banyak dibudidayakan dan memiliki tingkat konsumsi yang tinggi di Indonesia adalah Citrus reticulata Lour. atau jeruk keprok (Ashari, 1995). Jeruk keprok Garut merupakan salah satu komoditas pertanian unggulan nasional yang perlu terus dipertahankan dan ditingkatkan kualitas maupun kuantitas produksinya. Jeruk keprok Garut memiliki daging buah yang lunak, lembut dan banyak mengandung air. Rasanya manis agak masam yang segar, dan beraroma khas, karena bijinya sedikit, jeruk ini banyak dinikmati oleh masyarakat sebagai buah segar (Balitbangtan, 2012). Perkembangan jeruk keprok mengalami kendala karena produksinya bersifat musiman. Jeruk hanya dapat berbuah dalam beberapa bulan saja setiap musimnya. Menurut Darmawan (2014), produksi jeruk yang bersifat musiman ini tidak menguntungkan karena pada musim panen pasokan buah jeruk berlebih. Kemudian, pasokan buah jeruk impor pada saat tidak musim buah menyebabkan tidak stabilnya harga jual buah jeruk lokal di pasaran. Diperlukan teknik budidaya yang dapat mengatur produksi buah di luar musim untuk mengatasi permasalahan tersebut, sehingga pasokan buah jeruk diharapkan tersedia sepanjang tahun.

Terdapat berbagai metode induksi pembungaan yang dapat dilakukan secara buatan seperti penggunaan zat penghambat tumbuh, secara mekanis, dan manipulasi lingkungan. Retardan yang digunakan untuk pembungaan jeruk cukup banyak meliputi paclobutrazol, daminozide, cycocel, morphactin (Lizawati, 2008). Paclobutrazol paling sering digunakan dalam induksi pembungaan tanaman buah seperti jeruk, mangga, rambutan, dan kelengkeng. Paclobutrazol adalah zat penghambat tumbuh tanaman yang dapat menghambat biosintesis giberelin sehingga menurunkan pertumbuhan vegetatif dan merangsang pertumbuhan generatif berupa kuncup bunga. Namun penggunaan paclobutrazol dapat memberikan dampak negatif karena menimbulkan residu yang menghambat pertumbuhan vegetatif tanaman, bahkan pada beberapa daerah dapat mematikan pohon lebih dini.

Induksi pembungaan juga dapat dilakukan dengan secara mekanis seperti pelengkungan cabang, pencekikan batang (strangulasi), pemangkasan, penyungkupan, dan pengguguran daun. Azizu (2015) melaporkan bahwa pelengkungan cabang terbukti dapat menginduksi pembungaan tanaman jeruk keprok Borneo prima yang belum pernah berbunga selama 5 tahun semenjak tanam di lahan rawa Kalimantan Timur. Thamrin et al. (2009) mengatakan bahwa strangulasi dapat menginduksi pembungaan dan pembentukan buah jeruk pamelo. Menurut Rahayu dan Poerwanto (2014), pemangkasan adalah upaya membentuk tajuk atau akar tanaman sesuai dengan harapan petani baik dalam konteks pemeliharaan, pembersihan setelah panen raya dan induksi pembungaan. Pemangkasan bentuk tajuk tanaman jeruk dilakukan dengan cara pengurangan daun tidak produktif dan bertujuan untuk meratakan sinar matahari pada tajuk sehingga tanaman dapat optimal berfotosintesis. Pemangkasan tajuk dalam upaya untuk pembentukan kanopi seharusnya sudah dilakukan di masa awal pertumbuhan tanaman di lapang, misalnya 1-2 tahun pertama secara rutin. Menurut Geisler and Ferree (1984), pemangkasan akar merupakan salah satu teknik untuk menekan pertumbuhan tanaman apel yang umum dilakukan di negara maju. Penyungkupan tanaman dengan kain hitam juga biasa dilakukan petani buah di Taiwan dan Cina untuk merangsang pembungaan. Namun, penelitian mengenai pemangkasan akar dan penyungkupan pada tanaman jeruk keprok masih belum banyak dilaporkan.

Beragamnya teknik induksi pembungaan secara mekanis merupakan peluang untuk merakit teknologi budidaya Jeruk keprok Garut. Perlu dilakukan penelitian mengenai induksi pembungaan secara mekanis yang paling efektif 
dan lebih ramah lingkungan untuk menggantikan penggunaan paclobutrazol. Penelitian ini bertujuan untuk mendapatkan teknik induksi pembungaan tanaman yang efektif dalam menggantikan paclobutrazol untuk induksi pembungaan.

\section{BAHAN DAN METODE}

Penelitian dilaksanakan di Kebun
Percobaan Institut Pertanian Sindangbarang, Desa Sindangbarang, Kecamatan Bogor Barat, Kota Bogor, Jawa Barat yang merupakan daerah dataran rendah dengan ketinggian tempat $250 \mathrm{~m}$ dpl. Kegiatan penelitian dilaksanakan pada bulan Februari hingga November 2017 dengan curah hujan total 3283.3 mm dan 206 hari hujan.

Bahan yang digunakan tanaman jeruk keprok Garut yang sudah berumur 4 tahun, pupuk kandang, pupuk NPK dan paclobutrazol. Alat yang digunakan adalah alat pangkas untuk perawatan, kawat berdiameter $3 \mathrm{~mm}$, kain hitam, cangkul, label, ajir, meteran, dan alat tulis.

Penelitian ini dirancang dengan menggunakan Rancangan Kelompok Lengkap Teracak (RKLT) faktor tunggal yang terdiri dari 5 perlakuan yaitu kontrol (J1) atau tanpa perlakuan. Perlakuan strangulasi (J2) dilakukan dengan cara melilitkan kawat bediameter $3 \mathrm{~mm}$ yang di tekan kedalam batang tanaman sedalam diameter kawat sampai kulit batang terluka. Pelilitan dilakukan pada ketinggian $30 \mathrm{~cm}$ dari tanah kemudian dilepaskan 2 minggu setelah proses pelilitan. Perlakuan pemangkasan akar (J3) dilakukan dengan cara menggali tanah dibawah kanopi sedalam $30 \mathrm{~cm}$ dengan jarak 1 meter dari batang pohon. Perlakuan penyungkupan (J4) dilakukan dengan cara menutup atau membungkus tajuk dengan kain hitam sampai tajuk tertutupi oleh kain hitam setara dengan 95\% tertutupi naungan selama satu minggu. Perlakuan paclobutrazol (J5) dilakukan dengan cara diaplikasikan pada tanah sebanyak satu kali dengan dosis $10 \mathrm{ml}$ per tanaman. Aplikasi dilakukan ketika trubus sudah dewasa. Setiap perlakuan diulang sebanyak 5 kali, sehingga terdapat 25 satuan percobaan.

Percobaan dimulai dengan membersihkan gulma di sekitar tanaman secara mekanis maupun kimiawi. Tanaman yang digunakan pada percobaan ini adalah jeruk varietas keprok Garut sebanyak 25 tanaman dengan umur, ukuran tajuk, dan tinggi yang relatif seragam. Perlakuan strangulasi, pemangkasan akar, penyungkupan tajuk dan paclobutrazol dilakukan secara bertahap selama 2 dua hari, satu hari pertama pada blok 1, 2 dan 3 dan pada hari kedua pada blok 4 dan 5 .
Pemeliharaan tanaman terdiri dari pembersihan gulma, pemberian pupuk kandang dan pupuk NPK mutiara (16:16:16). Pemupukan NPK dilakukan seminggu sebelum perlakuan dengan dosis $500 \mathrm{~g}$ per pohon, pemupukan diberikan satu kali selama penelitian yaitu pada satu minggu sebelum perlakuan dan diberikan di sekeliling tanaman secara melingkar di bawah tajuk. Pengendalian hama/penyakit dan pemeliharaan dilakukan 2 kali pada masa penelitian.

Peubah yang diamati selama percobaan berlangsung adalah peubah pertunasan, pembungaan, dan pembuahan meliputi :

1. Jumlah tunas baru, yaitu banyaknya tunas yang muncul dimulai dari 1 MSP sampai 12 MSP.

2. Panjang tunas, pengukuran panjang tunas dihitung mulai dari pangkal tunas sampai ujung titik tumbuh, pengukuran dilakukan menggunakan penggaris setiap seminggu sekali selama pertumbuhan

3. Panjang daun, pengukuran panjang daun dilakukan pada daun ke-4 dari ujung tunas (16MSP).

4. Lebar daun, pengukuran lebar daun dilakukan pada daun ke-4 dari ujung tunas, pengambilan data dilakukan pada bagian daun paling lebar (16 MSP).

5. Periode tunas dan masa dorman, pengamatan periode tunas dilakukan dengan menghitung waktu dari muncul tunas sampai waktu tunas mulai dorman (ditandai dengan berhentinya pemanjangan tunas).

6. Minggu saat bunga muncul dari 2 MSP sampai 36 MSP.

7. Menghitung jumlah bunga, fruit set dan jumlah buah dari 2 MSP sampai 36 MSP.

Data diuji dengan analisis uji-F menggunakan perangkat lunak SAS (Statistical Analysis System).Hasil uji-F yang menunjukkan perbedaan nyata diuji lanjut dengan menggunakan Duncan Multiple Range Test (DMRT) pada taraf $5 \%$.

\section{HASIL DAN PEMBAHASAN}

\section{Kondisi Umum}

Perlakuan induksi pembungaan dilakukan di lahan terbuka seluas $\pm 3600 \mathrm{~m}^{2}$ di Kebun Percobaan IPB Sindangbarang. Data yang diperoleh dari Stasiun Klimatologi Dramaga (2017) menunjukkan bahwa suhu rata-rata harian pada bulan Februari-November 2017 sebesar $26.12{ }^{\circ} \mathrm{C}$. Curah hujan harian rata-rata di tempat penelitian pada bulan Februari-November 328.3 
2017 mencapai $352.1 \mathrm{~mm}$, dengan curah hujan tertinggi terjadi pada bulan Februari sebesar 526.3 $\mathrm{mm}$, dan jumlah curah hujan terendah terjadi pada bulan Agustus sebesar $179.2 \mathrm{~mm}$. total curah hujan sebesar $3283.3 \mathrm{~mm}$ dan mengalami hari hujan. Menurut Balijestro (2014) tanaman jeruk menghendaki suhu harian $13-35{ }^{\circ} \mathrm{C}$ dengan suhu optimum $22-23{ }^{\circ} \mathrm{C}$ serta curah hujan $1000-3000$ mm tahun ${ }^{-1}$ dengan curah hujan optimum 1 500-2 $500 \mathrm{~mm}^{\text {tahun }}{ }^{-1}$.

Gulma yang tumbuh pada daerah penelitian tanaman jeruk adalah gulma jenis putri malu (Mimosa pudica) dan alang-alang (Imperata cylindrica). Pengendalian dilakukan secara kimiawi dengan menggunakan bahan aktif isopropilamina gliphosat dan parakuat dikloroda dengan dosis masing-masing sebanyak $1.5 \mathrm{~L} \mathrm{ha}^{-1}$. Aplikasi herbisisda dilakukan sebanyak 2 kali yaitu pada saat persiapan lahan dan 2 bulan setelah persiapan lahan. Hama yang menyerang tanaman jeruk diantaranya semut rang-rang, belalang dan kutu putih yang menyebabkan rusaknya daun-daun muda serta percabangan tanaman jeruk. Pengendalian dilakukan secara kimiawi dengan bahan aktif deltamethrin sebanyak 2 kali pengendalian dengan dosis $1.5 \mathrm{~L}$ $\mathrm{ha}^{-1}$. Sedangkan penyakit yang menyerang tanaman adalah keriput daun yang menyebabkan daun dan tunas berubah warna menjadi kuning dan kerdil.

\section{Jumlah Tunas}

Perlakuan induksi pembungaan berpengaruh nyata terhadap jumlah tunas baru. Hasil pada Tabel 1 menunjukkan bahwa perlakuan penyungkupan tajuk menghasilkan jumlah terbanyak sebanyak 411.4 tunas baru dari minggu ke 2 sampai minggu ke 12 setelah perlakuan. Sedangkan jumlah tunas baru paling sedikit terdapat pada perlakuan strangulasi sebanyak 99.8 tunas baru. Menurut Sutisna (2010), induksi tunas lateral (tunas samping) merupakan suatu upaya untuk meningkatkan jumlah tajuk tiap tanaman, yang pada akhirnya diharapkan jumlah bunga yang terbentuk akan semakin meningkat.

Data yang disajikan dalam Tabel 1 juga menunjukkan lamanya periode tumbuh tunas dan lamanya masa dorman tunas. Lama periode tumbuh tunas merupakan waktu munculnya tunas baru sampai waktu tunas mulai memasuki masa dorman, sedangkan lama masa dorman tunas merupakan waktu dari mulai dorman sampai muncul tunas baru kembali. Hasil pengamatan menunjukkan bahwa perlakuan penyungkupan memberikan hasil yang lebih cepat dalam mempengaruhi waktu kemunculan dan panjang tunas baru sampai kondisi dorman dibandingkan perlakuan fisik lainnya termasuk kontrol. Penyungkupan selama satu minggu menyebabkan tanaman mengalami stres sehingga daun-daun mengalami keguguran. Selanjutnya tanaman jeruk mulai memasuki masa pemulihan pada minggu ke 2 pengamatan, yang ditandai dengan pertumbuhan tunas yang cukup lebat. Hasil ini sejalan dengan penelitian Rahayu dan Poerwanto (2014) yang menunjukkan bahwa tanaman jeruk keprok Borneo dengan perlakuan pemangkasan akan memunculkan tunas-tunas baru dan berkembang menjadi daun. Lama periode tumbuh tunas dan masa dorman yang diharapkan adalah yang paling pendek atau memiliki rentang waktu yang sempit sehingga diharapkan dapat mempercepat keluarnya tunas baru dan pertumbuhan tunas berlangsung cepat.

Selama pengamatan tanaman jeruk mengalami dua kali masa flushing (muncul tunas baru) namun tidak sampai masuk ke fase

Tabel 1. Pengaruh perlakuan terhadap jumlah tunas baru

\begin{tabular}{|c|c|c|c|c|c|c|}
\hline \multirow{2}{*}{ MSP } & \multicolumn{5}{|c|}{ Perlakuan } & \multirow{2}{*}{ Uji F } \\
\hline & Kontrol & Strangulasi & Pemangkasan Akar & Penyungkupan Tajuk & Paclobutrazol & \\
\hline 2 & $0.0 \mathrm{~b}$ & $0.0 \mathrm{~b}$ & $11.2 \mathrm{~b}$ & $239.8 \mathrm{a}$ & $0.0 \mathrm{~b}$ & ** \\
\hline 3 & $9.0 \mathrm{~b}$ & $3.4 \mathrm{~b}$ & $13.8 \mathrm{~b}$ & $349.6 a$ & $2.0 \mathrm{~b}$ & ** \\
\hline 4 & $23.6 \mathrm{~b}$ & $10.4 \mathrm{~b}$ & $26.2 \mathrm{~b}$ & $349.6 a$ & $33.6 \mathrm{~b}$ & ** \\
\hline 5 & $63.4 \mathrm{~b}$ & $30.4 \mathrm{~b}$ & $41.2 \mathrm{~b}$ & $352.2 \mathrm{a}$ & $59.6 \mathrm{~b}$ & ** \\
\hline 6 & $63.4 \mathrm{~b}$ & $37.4 \mathrm{~b}$ & $52.2 b$ & $354.0 \mathrm{a}$ & $59.6 \mathrm{~b}$ & ** \\
\hline 7 & $63.4 \mathrm{~b}$ & $37.4 \mathrm{~b}$ & $52.2 b$ & $354.0 \mathrm{a}$ & $59.6 \mathrm{~b}$ & ** \\
\hline 8 & $63.4 \mathrm{~b}$ & $37.4 \mathrm{~b}$ & $52.2 b$ & $354.0 \mathrm{a}$ & $59.6 \mathrm{~b}$ & ** \\
\hline 9 & $63.4 \mathrm{~b}$ & $37.4 \mathrm{~b}$ & $52.2 b$ & $354.0 \mathrm{a}$ & $59.6 \mathrm{~b}$ & ** \\
\hline 10 & $63.4 \mathrm{~b}$ & $37.4 \mathrm{~b}$ & $52.2 b$ & $354.0 \mathrm{a}$ & $59.6 \mathrm{~b}$ & ** \\
\hline 11 & $63.4 \mathrm{~b}$ & $37.4 \mathrm{~b}$ & $52.2 b$ & $375.6 \mathrm{a}$ & $59.6 \mathrm{~b}$ & ** \\
\hline 12 & $122.0 \mathrm{~b}$ & $99.8 \mathrm{~b}$ & $100.0 \mathrm{~b}$ & $411.4 \mathrm{a}$ & $129.0 \mathrm{~b}$ & ** \\
\hline
\end{tabular}

Keterangan : angka-angka yang diikuti oleh huruf yang sama pada baris yang sama menunjukan tidak berbeda nyata berdasarkan uji DMRT pada taraf 5\%, *: berpengaruh nyata pada taraf 5\%, **: sangat berpengaruh nyata pada taraf $1 \%$, MSP: minggu setelah perlakuan. 
generatif. Flushing pertama memiliki perbedaan waktu muncul tunas baru pada masing-masing perlakuan. Waktu muncul tunas tercepat dihasilkan pada perlakuan pemangkasan akar dan penyungkupan tajuk yaitu pada 2 MSP, sedangkan perlakuan kontrol, strangulasi dan paclobutrazol tunas baru muncul pada 3 MSP. Pada minggu ke 12 tunas baru tumbuh secara serentak pada semua perlakuan, hal ini menandakan bahwa pada minggu ke 11 setelah perlakuan tunas sudah dorman.

Hasil pada Tabel 1 juga menunjukkan setiap perlakuan memiliki rentang waktu muncul tunas yang berbeda-beda. Perlakuan pemangkasan akar menghasilkan rentang waktu muncul tunas paling lama dibanding dengan perlakuan kontrol, strangulasi, penyungkupan tajuk dan paclobutrazol. Lamanya muncul tunas setelah perlakuan pada pemangkasan akar terjadi selama 5 minggu, strangulasi dan penyungkupan tajuk berlangsung selama 4 minggu, dan kontrol serta paclobutrazol berlangsung selama 3 minggu berturut- turut.

\section{Panjang Tunas}

Hasil pada Tabel 2 menunjukkan bahwa perlakuan induksi pembungaan mempengaruhi secara sangat nyata panjang tunas jeruk keprok Garut. Perlakuan penyungkupan tajuk secara konstan berbeda nyata terhadap perlakuan lain. Pertumbuhan panjang tunas yang paling tinggi pada perlakuan penyungkupan diduga merupakan upaya tanaman untuk memperbaiki bentuk tajuknya. Penumpukan hormon auksin pada tanaman menjadi penyebab panjangnya tunas baru yang muncul pada tanaman jeruk yang telah mengalami keguguran daun setelah aplikasi penyungkupan. Banyaknya kandungan auksin pada tanaman akan mempengaruhi pertumbuhan tanaman karena auksin merupakan senyawa yang mendukung terjadinya pemanjangan sel pada pucuk (Abidin, 1987).

\section{Panjang dan Lebar Daun}

Hasil pada Tabel 3 menujukkan perlakuan fisik dan kimia mempengaruhi panjang dan lebar daun. Tanaman jeruk tanpa perlakuan (kontrol), strangulasi dan pemangkasan akar memiliki panjang daun lebih panjang dibandingkan dengan perlakuan penyungkupan dan paclobutrazol, namun perlakuan strangulasi dan pemangkasan akar tidak berbeda nyata secara stastistik. Hasil pengamatan menunjukkan bahwa perlakuan pemangkasan akar, penyungkupan tajuk dan paclobutrazol secara nyata memiliki lebar daun lebih sempit dibanding dengan kontrol. Secara umum perlakuan paclobutrazol memiliki daun yang lebih pendek sekaligus lebih sempit dibanding perlakuan lain dengan panjang daun $5.74 \mathrm{~cm}$ dan lebar $2.87 \mathrm{~cm}$. Pemberian paclobutrazol dalam jumlah sedikit dapat menghambat pertumbuhan dan pemanjangan sel. Paclobutrazol merupakan bahan penghambat biosintesa gibrelin, sehingga terjadi penghambatan terhadap pemanjangan sel (Berova et al., 2002).

Tabel 2. Pengaruh perlakuan terhadap panjang tunas $(\mathrm{cm})$

\begin{tabular}{|c|c|c|c|c|c|c|}
\hline \multirow{2}{*}{ MSP } & \multicolumn{5}{|c|}{ Perlakuan } & \multirow{2}{*}{ Uji F } \\
\hline & Kontrol & Strangulasi & Pemangkasan Akar & Penyungkupan Tajuk & Paclobutrazol & \\
\hline 2 & $0.00 \mathrm{~b}$ & $0.00 \mathrm{~b}$ & $0.00 \mathrm{~b}$ & $0.29 \mathrm{a}$ & $0.00 \mathrm{~b}$ & $* *$ \\
\hline 3 & $0.00 \mathrm{~b}$ & $0.00 \mathrm{~b}$ & $0.00 \mathrm{~b}$ & $2.72 \mathrm{a}$ & $0.00 \mathrm{~b}$ & ** \\
\hline 4 & $0.08 \mathrm{~b}$ & $0.09 \mathrm{~b}$ & $0.18 \mathrm{~b}$ & $5.93 \mathrm{a}$ & $0.21 \mathrm{~b}$ & ** \\
\hline 5 & $0.73 b$ & $0.90 \mathrm{~b}$ & $1.08 \mathrm{~b}$ & $9.47 \mathrm{a}$ & $1.42 \mathrm{~b}$ & ** \\
\hline 6 & $2.96 \mathrm{~b}$ & $2.37 \mathrm{~b}$ & $2.70 \mathrm{~b}$ & $10.13 a$ & $3.21 \mathrm{~b}$ & ** \\
\hline 7 & $5.22 b$ & $4.54 \mathrm{~b}$ & $4.70 \mathrm{~b}$ & $10.29 \mathrm{a}$ & $5.51 \mathrm{~b}$ & ** \\
\hline 8 & $7.08 \mathrm{~b}$ & $6.34 \mathrm{~b}$ & $6.44 \mathrm{~b}$ & $10.31 \mathrm{a}$ & $6.95 \mathrm{~b}$ & ** \\
\hline 9 & $7.92 b$ & $7.22 b$ & $7.05 \mathrm{~b}$ & $10.31 \mathrm{a}$ & $7.66 \mathrm{~b}$ & ** \\
\hline 10 & $7.98 \mathrm{~b}$ & $7.37 \mathrm{~b}$ & $7.25 \mathrm{~b}$ & $10.31 \mathrm{a}$ & $7.71 \mathrm{~b}$ & ** \\
\hline 11 & $7.99 b$ & $7.37 \mathrm{~b}$ & $7.25 b$ & $10.31 \mathrm{a}$ & $7.71 \mathrm{~b}$ & ** \\
\hline 12 & $7.99 \mathrm{~b}$ & $7.37 \mathrm{~b}$ & $7.25 b$ & $10.31 \mathrm{a}$ & $7.71 \mathrm{~b}$ & ** \\
\hline
\end{tabular}

Keterangan : angka-angka yang diikuti oleh huruf yang sama pada baris yang sama menunjukan tidak berbeda nyata berdasarkan uji DMRT pada taraf $5 \%, *$ : berpengaruh nyata pada taraf $5 \%, * *$ : sangat berpengaruh nyata pada taraf $1 \%$, MSP: minggu setelah perlakuan.

Tabel 3. Pengaruh perlakuan terhadap panjang dan lebar daun (cm) 16 MSP

\begin{tabular}{lccccc}
\hline \multirow{2}{*}{ Parameter } & \multicolumn{5}{c}{ Perlakuan } \\
\cline { 2 - 6 } & Kontrol & Strangulasi & Pemangkasan Akar & Penyungkupan Tajuk & Paclobutrazol \\
\hline Panjang daun & $6.33 \mathrm{a}$ & $6.06 \mathrm{ab}$ & $6.05 \mathrm{ab}$ & $5.86 \mathrm{~b}$ & $5.74 \mathrm{~b}$ \\
Lebar daun & $3.15 \mathrm{a}$ & $2.98 \mathrm{ab}$ & $2.96 \mathrm{~b}$ & $2.91 \mathrm{~b}$ & $2.87 \mathrm{~b}$ \\
\hline
\end{tabular}

Keterangan: angka-angka yang diikuti oleh huruf yang sama pada baris yang sama menunjukan tidak berbeda nyata berdasarkan uji DMRT pada taraf 5\%. 
Tabel 4. Jumlah tunas yang menghasilkan bunga, jumlah bunga dan jumlah buah.

\begin{tabular}{lccccc}
\hline \multirow{2}{*}{ Parameter } & \multicolumn{5}{c}{ Perlakuan } \\
\cline { 2 - 6 } & Kontrol & Strangulasi & Pemangkasan Akar & Penyungkupan Tajuk & Paclobutrazol \\
\hline Flushing 1 & TM & TM & TM & TM & TM \\
Flushing 2 & TM & TM & TM & TM & TM \\
Jumlah bunga & TM & TM & TM & TM & TM \\
Jumlah buah & TM & TM & TM & TM & TM
\end{tabular}

Keterangan: $\mathrm{TM}=$ tidak menghasilkan

\section{Induksi Pembungaan}

Hasil penelitian menunjukkan bahwa induksi pembungaan melalui perlakuan fisik dan kimia belum menghasilkan bunga selama 36 minggu pengamatan setelah perlakuan (Tabel 4), pada dua kali masa flushing belum ada tunas baru yang mengasilkan bunga pada masingmasing perlakuan. Sehingga tidak bisa menentukan persentase fruit set dan persentase gugur buah. Hasil ini sangat berbeda dengan penelitian Rai et al. (2004) bahwa perlakukan strangulasi dan paclobutrazol pada tanaman manggis dapat menginduksi pembugaan pada 41 hari dan 46 hari setelah perlakuan. Hasil penelitian Putra (2002) menunjukkan bahwa perlakuan stangulasi menginduksi pembungaan pada jeruk besar 'Nambangan' 6 minggu setelah perlakuan strangulasi. Curah hujan yang tinggi diduga menjadi penyebab kegagalan dalam induksi pembungaan tersebut. Menurut Bernier et al. (1985), terdapat dua teori pembungaan, yaitu teori pertama menyatakan bahwa inisiasi pembungaan pada tanaman tidak akan terjadi kecuali ada stimulasi, sedangkan teori kedua menyatakan bahwa tanaman selalu berpotensi berbunga tetapi kadang-kadang tertekan oleh kondisi lingkungan yang tidak sesuai.

\section{KESIMPULAN}

Hasil menunjukkan bahwa semua perlakuan tidak menginduksi pembungaan sampai minggu ke36 setelah perlakuan. Perlakuan induksi pembungaan secara mekanis seperti penyungkupan tajuk pada tanaman jeruk keprok garut mempengaruhi jumlah tunas dan panjang tunas lebih baik dibandingkan dengan perlakuan paclobutrazol.

\section{DAFTAR PUSTAKA}

Abidin, Z. 1987. Dasar-dasar Pengetahuan Tentang Zat Pengatur Tumbuh. Angkasa. Bandung.

Ashari, S. 1995. Hortikultura Aspek Budidaya. UIPress. Jakarta.

Azizu, M.N. 2015. Pelengkungan cabang dan pemupukan jeruk keprok Borneo Prima pada periode transisi di lahan rawa Kabupaten Paser Kalimantan Timur. [Tesis]. Institut Pertanian Bogor. Bogor.

[Balijestro] Balai Penelitian Tanaman Jeruk dan Buah Subtropik. 2014. Panduan budidaya tanaman jeruk. http;//balijestro.litbang. pertanian.go.id. [11 Agustus 2017].

[Balitbangtan] Balai Penelitian dan Pengembangan Pertanian. 2012. Varietas Jeruk Unggulan Nasional. Siap Menggilas Buah Impor. Kementerian Pertanian. Jakarta.

Bernier, G, J.M. Kinet, R.M. Sachs.1985. The Physiology of Flowering. Vol 1. The Initation of Flowers. CRC Press Inc. Florida.

[BPS] Biro Pusat Statistik. 2015. Statistik Indonesia. Produksi buah-buahan di Indonesia tahun 2010-2014. http://bps.go.id. [3 Desember 2016].

Darmawan. M. 2014. Induksi pembungaan di luar musim pada tanaman jeruk keprok (Citrus reticulate). [Tesis]. Institut Pertanian Bogor. Bogor.

[Ditjenhort] Direktorat Jenderal Hortikultura. 2014. Rencana strategis Direktorat Jenderal Hortikultura Tahun 2015-2019. http://horti kultura.pertanian.go.id/?page_id $=195$. [3 Desember 2016].

Geisler, D., D.C. Ferree. 1984. The influence of root pruning and water relation, net photosynthesis, and growth of young Golden Delicious apple tree. Journal of the American Society for Horticultural Science. 109:827-831.

Lizawati. 2008. Induksi pembungaan dan pembuahan tanaman buah dengan penggunaan retardant. J.Agron. 12(2):18-22.

Nafisah, S.N., Suharno, N. Tinaprilla. 2013. Sikap dan persepsi konsumen terhadap jeruk lokal dan jeruk impor di pasar modern Kota Bogor. Forum Agribisnis. 4(1):71-84.

Putra, G.A. 2002. Pengaruh strangulasi terhadap pembungaan jeruk besar 'Nambangan'. [Tesis]. Institut Pertanian Bogor. Bogor. 
Rahayu, R.S., R. Poerwanto. 2014. Optimasi pertumbuhan vegetatif dan keragaan tanamanjeruk keprok Borneo Prima (Citrus reticulata cv. Borneo Prima) melalui pemangkasan dan pemupukan. J. Hort. Indonesia. 5(2):95-103.

Respati, E., W.B. Komalasari, S. Wahyuningsih, M. Manurung. 2015. Buletin Triwulanan Ekspor Impor Volume VII Nomor 1 Tahun 2015. Sabarella (ed.). Pusdatin Kementrian Pertanian. Jakarta Selatan.

Rai, I.N., R. Poerwanto, L.K. Darusman, B.S. Purwoko. 2004. Pengaturan pembungaan tanaman mangis (Garcinia mangostana L.) di luar musim dengan strangulasi, serta aplikasi paclobutrazol dan etepon. Bul. Agron. 32(2):12-20.
Sutisna, A. 2010. Teknik mempercepat pertumbuhan tunas lateral utuk perbanyakan vegetatif anthurium dengan aplikasi GA dan BA. Bul. Teknik pertanian. 15(2):56-59.

Thamrin, M., S. Susanto, E. Santosa. 2009. Efektivitas strangulasi terhadap pembungaan tanaman jeruk pamelo 'Cikoneng' (Citrus grandis (1.) osbeck) pada tingkat beban buah sebelumnya yang berbeda. J. Agron. Indones. 37(1):40-45. 